\title{
Determination of optimal doses of glyphosate for controlling weeds at several stages in southwestern Buenos Aires province (Argentina)
}

\author{
Diego Javier Bentivegna ${ }^{1 *}$, Gisela Lorena Moyano², \\ Juan Facundo Fabián Daddario ${ }^{1,3}$, Guillermo Tucat ${ }^{1}$ \\ ${ }^{1}$ Center of Renewable Natural Resources of the Semiarid Zone (CERZOS), National University of the South (UNS), \\ The National Research Council of Argentina (CONICET), Carrindanga Road Km 7, Bahía Blanca, Argentina \\ ${ }^{2}$ Biology Department, National University of the South, 670 San Juan Street, 8000, Bahía Blanca, Argentina \\ ${ }^{3}$ Agronomy Department, National University of the South, 800 San Andres Street, 8000, Bahía Blanca, Argentina
}

\section{Vol. 57, No. 4: 347-354, 2017}

DOI: 10.1515/jppr-2017-0047

Received: July 27, 2017

Accepted: October 6, 2017

${ }^{*}$ Corresponding address:

dbentive@criba.edu.ar

\begin{abstract}
Efficient weed management is essential for avoiding competition for water, light, and nutrient resources in semiarid zones. Chemical weed control with glyphosate was evaluated on perennial wall-rocket (Diplotaxis tenuifolia), artichoke thistle (Cynara cardunculus), slender wild oat (Avena barbata), and perennial ryegrass (Lolium perenne). Plants at early, middle and advanced vegetative stages were used in this study. Glyphosate potassium salt was applied at rates of $0.0675(1 / 16 x), 0.135(1 / 8 x), 0.27(1 / 4 x), 0.54(1 / 2 x), 1.08(x)$ and $2.16(2 \mathrm{x}) \mathrm{kg}$ acid equivalent $(\mathrm{ae}) \cdot \mathrm{ha}^{-1}$. Glyphosate combined with $2,4-\mathrm{D}$ amine salt was evaluated at rates of $1.08 \mathrm{~kg}$ ae $\cdot \mathrm{ha}^{-1}$ and $0.53 \mathrm{~kg}$ active ingredient (ai) $\cdot \mathrm{ha}^{-1}$, respectively. The volume of the spray was $100 \mathrm{l} \cdot \mathrm{ha}^{-1}$ with 86 droplets $\cdot \mathrm{cm}^{-2}$ and a Volume Median Diameter (VMD) of $421.19 \mu \mathrm{m}$. In general, all the tested weeds were controlled with a quarter of the label rate. Three sizes of tested plants were controlled in a similar way at the same glyphosate dose rate. Moreover, the addition of 2,4-D to glyphosate did not produce an increase in the control of broadleaf weeds. The results showed that glyphosate was effective in controlling the tested weed species, including low application rates for all the growth stages in the southwestern Buenos Aires province.
\end{abstract}

Key words: 2,4-D, glyphosate, grasses, phenology, weed control

\section{Introduction}

The southwestern part (SW) of Buenos Aires province is characterized by a mixed farming system, which includes the raising of livestock and cereal production. There are more rangelands and pasturelands than croplands and cover about $70 \%$ of the total area. However, despite this fact this region makes a significant contribution to the cereal grain production in Argentina. The principal crops in the SW of Buenos Aires province are: wheat (Triticum aestivum L.), barley (Hordeum vulgare L.) and oats (Avena sativa L.) (Scursoni et al. 2014).

Several environmental factors limit crop production such as unfavorable climatic and edaphic conditions. For instance, low rainfall (about $580 \mathrm{~mm}$ ), irregular fluctuation of dry and wet years, and water stress conditions at the end of spring usually occur in the area (Paoloni 2010). In addition, shallow soil depth $(<0.9 \mathrm{~m})$ together with low organic matter $(<3 \%)$ limits the water storage capacity (Paoloni 2010). As a consequence, water is the principal resource primarily affecting grain yield. Thus, due to the weed competition for limited water, nutrient and light, efficient weed management is essential for the development of the area.

Different surveys conducted in the SW have determined the presence of approximately 85 plant species considered as weeds. Grasses are the most troublesome, 
such as ryegrass (Lolium perenne L.) and wild oats (Avena fatua L.). Lolium species have shown the highest constancy in the SW, reaching values above 50\% in the last thirty years (Istilart and Yanniccari 2013). Lolium multiflorum L. and L. perenne are the main competitors in wheat fields (Yanniccari 2014). Similarly, A. fatua and A. barbata showed elevated degrees of infestation that greatly reduce grain production (Lamberto et al. 1997; Gigón et al. 2009; Scursoni et al. 2014). Due to their survival strategies, together with a highly competitive growth habit, they are considered difficult to control in wheat fields (Juan et al. 1995).

Among the broadleaf species, the Asteraceae and Brassicaceae families showed the greatest number of species cited in the field surveys (Gigón et al. 2009; Scursoni et al. 2014). Within the Brassicaceae family, Diplotaxis tenuifolia L. (DC) (perennial wall-rocket) is the most important weed in the region, which is known to deplete soil nutrients and moisture. Another relevant broadleaf weed in the SW of Buenos Aires province is Cynara cardunculus L. (artichoke thistle, Asteraceae), which has been declared a national pest in Argentina since 1963 (Lamberto et al. 1997).

Due to reduction of aggregate size and increasing wind erosion, a typical situation in this region, mechanical control is not the best option for reducing weed infestation (Alvarez and Steinbach 2009), therefore weed management is mainly based on chemical control (Istilart and Yanniccari 2013). In addition, applications are commonly characterized by a mixture of glyphosate and 2,4-D to achieve the highest control of the vegetation (Skelton 2016).

Sustainable use of herbicides requires efficient and rational applications in order to maximize results and to avoid associated environmental problems. Principally, this includes the use of proper rates, tank mixing effective synergistic, herbicides with distinct modes of action, application at appropriate stages and under optimal environmental conditions (Ganie et al. 2017) taking into consideration the effect of environment on herbicide efficacy.

Many factors influence the correct rate of herbicide to be used, but weed size and application conditions are considered to be the most important ones (Knoche 1994; Fig. 1). In general, small plants are more sensitive than large plants, requiring lower rates of herbicides to achieve the proper phytotoxic effect. Moreover, the utilization of the appropriate volume, droplet size, droplet number, and adjuvants improves herbicide deposition on the plant and avoids the drift (Esehaghbeygi et al. 2011).

The use of glyphosate formulations has been widely studied on several weeds as well as the optimal conditions of application (Baylis 2000); however, there is little information regarding the efficient use of glyphosate on regionally troublesome weeds.

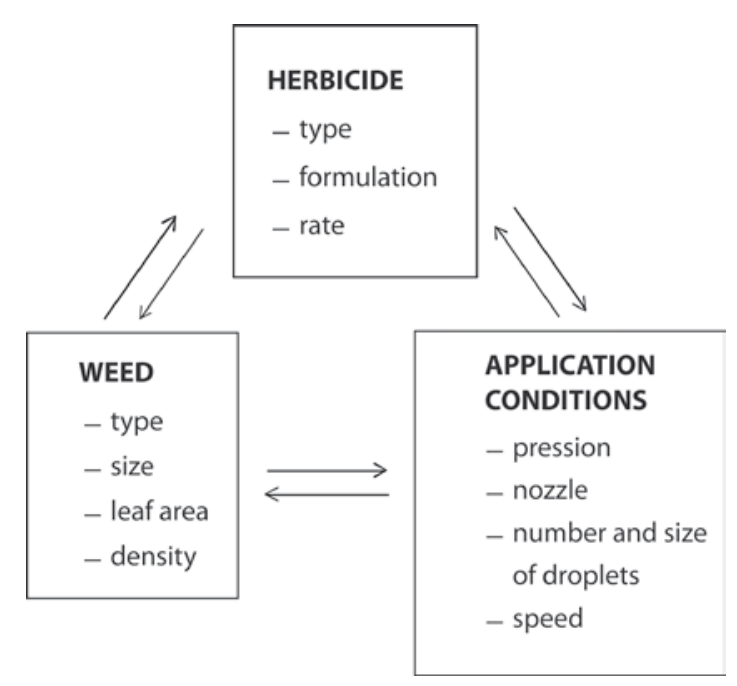

Fig. 1. Parameters involved in the herbicide applications for weed control

We hypothesized that large plants require higher doses of glyphosate than small ones, and that this amount can be reduced with the incorporation of 2,4-D in tank mixing. Therefore, the objectives of this study were to determine: i) the optimal dose of glyphosate to control regional weeds at different stages and ii) if glyphosate combined with 2,4-D would improve broadleaf weed control.

\section{Materials and Methods}

The experiments were conducted at the Center of Renewable Natural Resources of Semiarid Zone (CERZOS) (CCT-CONICET, Bahía Blanca, -38³9'54.56”S - 62 $2^{\circ} 14^{\prime} 2.70$ ” W) in 2012-2013 to determine the glyphosate dose response, and the interaction of glyphosate plus 2,4-D on weeds including: $D$. tenuifolia, C. cardunculus, A. barbata, L. perenne.

Weed seeds were collected in spring 2012 from several populations located in Bahía Blanca, Buenos Aires province, Argentina. Harvested seeds were cleaned and stored at a low temperature $\left(4^{\circ} \mathrm{C}\right)$ in sealed paper bags. Seeds were germinated in 9-cm Petri dishes containing a sheet of coarse filter paper, previously soaked in distilled water. Petri dishes were placed inside a growth chamber at a constant temperature $\left(24^{\circ} \mathrm{C}\right)$. Once seeds germinated, 4 seedlings were transplanted at a depth of $1 \mathrm{~cm}$ each in black plastic pot containing sandy loam soil ( $64 \%$ sand, $15 \%$ silt, and $21 \%$ clay), representative of the region. Plants were grown under greenhouse conditions $\left(25 \pm 4.6^{\circ} \mathrm{C} ; 42 \pm 22 \%\right.$ relative humidity) until establishment. Then, the pots were placed outside the greenhouse for acclimatization to natural conditions.

Glyphosate potassium salt was applied at rates of $0.0675,0.135,0.27,0.54,1.08$ and $2.16 \mathrm{~kg}$ acid 
equivalent $(\mathrm{ae}) \cdot \mathrm{ha}^{-1}$. To determine the interaction of the herbicides, an additional treatment of glyphosate combined with 2,4-D amine salt was evaluated at rates of $1.08 \mathrm{~kg}$ ae $\cdot \mathrm{ha}^{-1}$ and $0.53 \mathrm{~kg}$ active ingredient (ai) $\cdot \mathrm{ha}^{-1}$, respectively. Rates were selected according to the label recommendations for similar weeds. Control treatments were sprayed with water only. Another set of pots, untreated at the time of application, were harvested and characterized morphologically. The plant height and weight were recorded and leaves were digitalized to calculate leaf perimeter and area, using software Image J (Abramoff et al. 2004). The herbicide treatments were applied at three phenological stages on all the species (Tables 1, 2).

Herbicide treatments were sprayed on September 19, 2013. One month after the herbicide applications, the plants that survived from each pot were harvested, put into paper bags, and dried at $60^{\circ} \mathrm{C}$ until constant weight. After analyzing the morphological characteristics of plants at the moment of application leaf number, leaf area, leaf perimeter, and total dry weight and height were found to differ significantly between the different phenological stages (Table 2).

\section{Application conditions}

Herbicide treatments were applied using a spray chamber calibrated to deliver a spray solution of $100 \mathrm{l} \cdot \mathrm{ha}^{-1}$ at $255 \mathrm{kPa}$ using a constant speed of $3.77 \mathrm{~km} \cdot \mathrm{h}^{-1}$. The spray chamber held an 11002 nozzle with a 50 mesh filter. Water-sensitive cards were sprayed to determine the droplet spectrum (precise droplet size and amount) using DepositScan software (Zhu et al. 2011). The average volumetric diameter and number of droplets per unit area $\left(\mathrm{drop} \cdot \mathrm{cm}^{-2}\right)$ were calculated on three sites of each water-sensitive card. Average droplet number per area was 86 droplets $\cdot \mathrm{cm}^{-2}\left(20-30\right.$ droplets $\cdot \mathrm{cm}^{-2}$ are recommended for systemic herbicides), while the average Volume Median Diameter (VMD) was $421.19 \mu \mathrm{m}$. An adequate distribution of droplets on the cards was obtained. The VMD was higher than the minimum recommended $(210 \mu \mathrm{m})$ to avoid herbicide drift (Esehaghbeygi et. al. 2011). In our case, a greater number of droplets and a high VMD allowed an adequate cover and gave a high impact. The data obtained indicate that the applications were performed efficiently.

Table 1. Characterization of phenological stages for each species tested

\begin{tabular}{lccc}
\hline \multirow{2}{*}{ Phenological stage } & Number of true leaves & \multicolumn{2}{c}{ Height $[\mathrm{cm}]$} \\
\cline { 3 - 4 } & $2-4$ & broadleaf species & grasses \\
\hline Early & $4-6$ & $5-10$ & $26-30$ \\
Middle & more than 6 & $10-20$ & $30-36$ \\
Advanced & $20-35$ & $36-45$ \\
\hline
\end{tabular}

Table 2. Mean values of leaf number, leaf area, leaf perimeter, leaf dry weight and height of grasses and broadleaf species before the herbicide application

\begin{tabular}{|c|c|c|c|c|c|c|}
\hline Species & $\begin{array}{l}\text { Phenological } \\
\text { stage }\end{array}$ & No. leaves & $\begin{array}{c}\text { Leaf area } \\
{\left[\mathrm{cm}^{2}\right]}\end{array}$ & $\begin{array}{c}\text { Leaf perimeter } \\
{[\mathrm{cm}]}\end{array}$ & $\begin{array}{l}\text { Dry weight } \\
{[\mathrm{g}]}\end{array}$ & $\begin{array}{l}\text { Height } \\
{[\mathrm{cm}]}\end{array}$ \\
\hline \multicolumn{7}{|c|}{ Broadleaf } \\
\hline \multirow{3}{*}{$\begin{array}{l}\text { Diplotaxis tenuifolia } \\
\text { (Perennial wall-rocket) }\end{array}$} & early & 4 & 0.7 & 8.4 & 0.012 & 2.5 \\
\hline & middle & 6 & 1.9 & 14.0 & 0.0807 & 5 \\
\hline & advanced & 11 & 6.6 & 29.2 & 0.38 & 13 \\
\hline \multirow{3}{*}{$\begin{array}{l}\text { Cynara cardunculus } \\
\text { (Artichoke thistle) }\end{array}$} & early & 5 & 3.9 & 19.6 & 0.060 & 15 \\
\hline & middle & 4 & 11.5 & 31.9 & 0.1811 & 20 \\
\hline & advanced & 5 & 21.5 & 58.3 & 0.7547 & 40 \\
\hline \multicolumn{7}{|c|}{ Grasses } \\
\hline \multirow{3}{*}{$\begin{array}{l}\text { Avena barbata } \\
\text { (Slender wild oat) }\end{array}$} & early & 3 & 6.7 & 87.6 & 0.099 & 20 \\
\hline & middle & 4 & 6.2 & 82.5 & 0.1815 & 25 \\
\hline & advanced & 5 & 6.3 & 64.2 & 0.3187 & 64 \\
\hline \multirow{3}{*}{$\begin{array}{l}\text { Lolium perenne } \\
\text { (Perennial ray grass) }\end{array}$} & early & 4 & 3.8 & 81.1 & 0.051 & 21 \\
\hline & middle & 4 & 10.5 & 117.2 & 0.1224 & 26 \\
\hline & advanced & 5 & 6.2 & 96.7 & 0.2970 & 29 \\
\hline
\end{tabular}




\section{Statistical analysis}

The pots were arranged in a completely randomized design with four replicates. A four-parameter log-logistic model was used to describe biomass reduction at different herbicide rates (Seefeldt et al. 1995):

$$
\mathrm{y}=\mathrm{C}+\frac{\mathrm{D}-\mathrm{C}}{1+\left(\frac{\mathrm{x}}{\mathrm{I}_{50}}\right)^{b}}
$$

where: $\mathrm{y}$ - plant biomass, $\mathrm{C}$ - the lower limit, D - the upper limit, $\mathrm{b}$ - the slope, $\mathrm{I}_{50}$ - dose giving $50 \%$ control, $\mathrm{x}$ - the applied dose.

To determine the precise differences between herbicide treatments within each growth stage, it is recommended to pursue an analysis of variance (ANOVA) (Seefeldt et al. 1995). Our data were subjected to ANOVA with fixed effect of herbicide dose. The test of normality for Shapiro Wilk and analysis of residuals for equal variance were determined with a probability of $p \leq 0.05$. The means were separated using Fisher's Protected LSD test $(p<0.05)$. The software used for statistical analysis was INFOSTAT (Di Rienzo et al. 2015).

\section{Results and Discussion}

\section{Glyphosate control}

Glyphosate application and the growth stages showed an interaction at 30 days after treatments (Tables 3, 4). The regression analysis parameters are presented separately for each growth stage in Table 5. Most of the species were controlled with a small amount of glyphosate $\left(0.27 \mathrm{~kg} \mathrm{ae} \cdot \mathrm{ha}^{-1}\right)$ except for $A$. barbata at the advanced phenological stage. This application rate was equivalent to a quarter of the label rate, which suggested a high susceptibility of the tested species. It is noteworthy that effective control can only be achieved when application conditions are optimal, such as in this study.

The plants were stunted when they were sprayed with glyphosate at $0.135 \mathrm{~kg}$ ae $\cdot \mathrm{ha}^{-1}$ compared with the untreated plants (Table 3). This dose did not kill the plants, but it was sufficient to reduce their size. Interestingly, despite the anatomical and morphological differences between plants belonging to different stages, the control was similar in all species at the same dose. Apparently, the optimal sprayer conditions achieved in

Table 3. Average height $(\mathrm{cm})$ of Diplotaxis tenuifolia, Cynara cardunculus, Avena barbata, Lolium perenne at three vegetative stages (early, middle, advanced) after increasing the glyphosate rates, evaluated at 30 days after treatments

\begin{tabular}{|c|c|c|c|c|c|c|c|c|c|c|c|c|}
\hline \multirow{2}{*}{$\begin{array}{c}\text { Rate } \\
{\left[\mathrm{kg} \mathrm{ae} \cdot \mathrm{ha}^{-1}\right]}\end{array}$} & \multicolumn{3}{|c|}{ D. tenuifolia } & \multicolumn{3}{|c|}{ C. cardunculus } & \multicolumn{3}{|c|}{ A. barbata } & \multicolumn{3}{|c|}{ L. perenne } \\
\hline & early & middle & advanced & early & middle & advanced & early & middle & advanced & early & middle & advanced \\
\hline 0 & $8 \mathrm{a}$ & $11 \mathrm{a}$ & $17.5 \mathrm{a}$ & $13.75 \mathrm{a}$ & $19.75 \mathrm{a}$ & $30.25 \mathrm{a}$ & $31.25 \mathrm{a}$ & $18.25 \mathrm{a}$ & $84.5 \mathrm{a}$ & $26.75 \mathrm{a}$ & $27.5 \mathrm{a}$ & $34.75 \mathrm{a}$ \\
\hline 0.0675 & $6.5 \mathrm{a}$ & $10 a$ & $19 a$ & $11.5 \mathrm{a}$ & $17.5 \mathrm{~b}$ & $24.5 \mathrm{a}$ & $26.25 \mathrm{~b}$ & $15.5 \mathrm{a}$ & $74.5 \mathrm{a}$ & $25.75 a$ & $26.75 a b$ & $28 \mathrm{~b}$ \\
\hline 0.135 & $1.25 \mathrm{~b}$ & $4.5 \mathrm{~b}$ & $11.25 \mathrm{~b}$ & $3.5 \mathrm{~b}$ & $0 \mathrm{c}$ & $10.5 \mathrm{~b}$ & $6.5 \mathrm{c}$ & $16.75 \mathrm{ab}$ & $56.25 \mathrm{~b}$ & $0 c$ & $25.75 \mathrm{~b}$ & $16 \mathrm{c}$ \\
\hline 0.27 & $0 \mathrm{~b}$ & $0 \mathrm{c}$ & $3.25 c$ & $0 \mathrm{c}$ & $0 \mathrm{c}$ & $0 \mathrm{e}$ & $0 d$ & $0 \mathrm{c}$ & $33 c$ & $0 c$ & $0 \mathrm{c}$ & $0 d$ \\
\hline 0.54 & $0 \mathrm{~b}$ & $0 \mathrm{c}$ & $0 d$ & $0 \mathrm{c}$ & $0 \mathrm{c}$ & $4.75 d$ & $0 d$ & $0 \mathrm{c}$ & $0 d$ & $0 \mathrm{c}$ & $0 \mathrm{c}$ & $0 d$ \\
\hline 1.08 & $0 \mathrm{~b}$ & $0 c$ & $0 d$ & $0 \mathrm{c}$ & $0 c$ & $2.75 \mathrm{ed}$ & $0 d$ & $0 \mathrm{c}$ & $0 d$ & $0 c$ & $0 c$ & $0 d$ \\
\hline 2.16 & $0 \mathrm{~b}$ & $0 \mathrm{c}$ & $0 d$ & $0 \mathrm{c}$ & $0 \mathrm{c}$ & $0 \mathrm{e}$ & $0 d$ & $0 \mathrm{c}$ & $0 d$ & $0 c$ & $0 \mathrm{c}$ & $0 \mathrm{~d}$ \\
\hline
\end{tabular}

Means with the same letter in the same column do not show any significant differences according to LSD Fisher test ( $p<0.05$ )

Table 4. Average biomass (g DM) of Diplotaxis tenuifolia, Cynara cardunculus, Avena barbata, Lolium perenne at three vegetative stages (early, middle, advanced) after increasing the glyphosate rates evaluated at 30 days of treatments

\begin{tabular}{|c|c|c|c|c|c|c|c|c|c|c|c|c|}
\hline \multirow{2}{*}{$\begin{array}{c}\text { Rate } \\
{\left[\mathrm{kg} \mathrm{ae} \cdot \mathrm{ha}^{-1}\right]}\end{array}$} & \multicolumn{3}{|c|}{ D. tenuifolia } & \multicolumn{3}{|c|}{ C. cardunculus } & \multicolumn{3}{|c|}{ A. barbata } & \multicolumn{3}{|c|}{ L. perenne } \\
\hline & early & middle & advanced & early & middle & advanced & early & middle & advanced & early & middle & advanced \\
\hline 0 & $0.037 b$ & $0.086 a$ & $0.332 \mathrm{a}$ & $0.247 \mathrm{a}$ & $0.047 a$ & $1.223 \mathrm{a}$ & $0.207 a$ & $0.378 a$ & $1.034 \mathrm{a}$ & $0.409 a$ & $0.422 \mathrm{a}$ & $0.318 a$ \\
\hline 0.0675 & $0.065 a$ & $0.084 a$ & $0.245 b$ & $0.175 b$ & $0.288 \mathrm{~b}$ & $1.087 \mathrm{a}$ & $0.280 \mathrm{a}$ & $0.307 a$ & $0.775 \mathrm{~b}$ & $0.288 a$ & $0.651 \mathrm{~b}$ & $0.842 \mathrm{~b}$ \\
\hline 0.135 & $0.012 b c$ & $0.07 a$ & $0.07 \mathrm{~b}$ & $0.043 c$ & $0 \mathrm{c}$ & $1.048 \mathrm{a}$ & $0.073 \mathrm{~b}$ & $0.141 \mathrm{~b}$ & $0.497 \mathrm{c}$ & $0 \mathrm{~b}$ & $0.318 \mathrm{~b}$ & $0.115 c$ \\
\hline 0.27 & $0 \mathrm{c}$ & $0 \mathrm{~b}$ & $0 \mathrm{c}$ & $0 \mathrm{c}$ & $0 c$ & $0 \mathrm{~b}$ & $0 \mathrm{~b}$ & $0 \mathrm{c}$ & $0.537 c$ & $0 \mathrm{~b}$ & $0 c$ & $0 d$ \\
\hline 0.54 & $0 \mathrm{c}$ & $0 \mathrm{~b}$ & $0 c$ & $0 \mathrm{c}$ & $0 c$ & $0.094 \mathrm{~b}$ & $0 \mathrm{~b}$ & $0 \mathrm{c}$ & $0 d$ & $0 \mathrm{~b}$ & $0 c$ & $0 d$ \\
\hline 1.08 & $0 \mathrm{c}$ & $0 \mathrm{~b}$ & $0 c$ & $0 \mathrm{c}$ & $0 \mathrm{c}$ & $0.067 b$ & $0 \mathrm{~b}$ & $0 \mathrm{c}$ & $0 d$ & $0 \mathrm{~b}$ & $0 \mathrm{c}$ & $0 \mathrm{~d}$ \\
\hline 2.16 & $0 \mathrm{c}$ & $0 \mathrm{~b}$ & $0 \mathrm{c}$ & $0 \mathrm{c}$ & $0 \mathrm{c}$ & $0 \mathrm{~b}$ & $0 \mathrm{~b}$ & $0 \mathrm{c}$ & $0 \mathrm{~d}$ & $0 \mathrm{~b}$ & $0 \mathrm{c}$ & $0 \mathrm{~d}$ \\
\hline
\end{tabular}

Means with the same letter in the same column do not show any significant differences according to LSD Fisher test $(p<0.05)$ 
Table 5. Regression parameters, model goodness of fit parameters, coefficient of determination and effective doses reached in the control experiments of Diplotaxis tenuifolia, Cynara cardunculus, Avena barbata, Lolium perenne at three phenological stages

\begin{tabular}{|c|c|c|c|c|c|c|c|c|c|}
\hline \multirow[t]{2}{*}{ Species } & \multirow{2}{*}{$\begin{array}{c}\text { Phenological } \\
\text { stage }\end{array}$} & \multicolumn{3}{|c|}{ Parameters } & \multicolumn{2}{|c|}{$\begin{array}{l}\text { Model goodness } \\
\text { of fit }\end{array}$} & \multirow{2}{*}{$\begin{array}{c}\begin{array}{c}\text { Coefficient of } \\
\text { determination }\end{array} \\
R^{2}\end{array}$} & \multicolumn{2}{|c|}{ Effective doses } \\
\hline & & $C$ & $\mathrm{D}$ & $b$ & RMSE & $\mathrm{EF}$ & & $I_{50}$ & $I_{90}$ \\
\hline \multirow{3}{*}{ D. tenuifolia } & early & $-1.00 \mathrm{E}-09$ & 0.05 & 26.3 & 0.0178 & -0.2578 & 0.64 & 0.13 & 0.14 \\
\hline & middle & $-1.00 \mathrm{E}-05$ & 0.08 & 12.8 & 0.0123 & -0.0096 & 0.93 & 0.28 & 0.32 \\
\hline & advanced & -0.01 & 0.32 & 1.81 & 0.0547 & -0.0485 & 0.83 & 0.24 & 0.98 \\
\hline \multirow{3}{*}{ C. cardunculus } & early & -0.001 & 0.25 & 3.53 & 0.0441 & -0.0021 & 0.84 & 0.09 & 0.16 \\
\hline & middle & $-8.7 \mathrm{E}-09$ & 0.45 & 24.14 & 0.0686 & -0.0329 & 0.88 & 0.07 & 0.07 \\
\hline & advanced & 0.04 & 1.15 & 27.49 & 0.2691 & -0.0430 & 0.83 & 0.15 & 0.16 \\
\hline \multirow{3}{*}{ A. barbata } & early & -1.4 & 0.24 & 22.73 & 0.0622 & -0.1273 & 0.77 & 0.13 & 0.14 \\
\hline & middle & -0.004 & 0.37 & 3.21 & 0.0851 & -0.1964 & 0.81 & 0.11 & 0.22 \\
\hline & advanced & -0.11 & 1.02 & 1.22 & 0.1746 & -0.9420 & 0.86 & 0.20 & 0.66 \\
\hline \multirow{3}{*}{ L.perenne } & early & $-4.24 \mathrm{E}-09$ & 0.41 & 25.45 & 0.1361 & -0.0005 & 0.62 & 0.07 & 0.07 \\
\hline & middle & -2.6 & 0.54 & 36.14 & 0.1131 & -0.9739 & 0.86 & 0.14 & 0.14 \\
\hline & advanced & $-2.7 \mathrm{E}-09$ & 0.61 & 26.96 & 0.1452 & -5.5388 & 0.8 & 0.13 & 0.14 \\
\hline
\end{tabular}

$\mathrm{C}$ - the lower limit, D - the upper limit, $\mathrm{b}$ - the slope, RMSE - root mean square error, EF - modelling efficiency coefficient, $\mathrm{R}^{2}-$ coefficient of determination, $\mathrm{I}_{50}$ - dose giving $50 \%$ of control, $\mathrm{I}_{90}$ - dose giving $90 \%$ control

this study resulted in all the doses having similar effects on different plant sizes.

Figure 1 shows three important parameters involved in successful weed control. Our study indicated that a specific herbicide (glyphosate) sprayed under effective conditions resulted in successful control depending on the stage of plant growth.

\section{Diplotaxis tenuifolia}

Firstly, the highest efficacy (100\% control) was obtained when glyphosate was applied at half of the recommended dose $\left(0.27 \mathrm{~kg}\right.$ ae $\left.\cdot \mathrm{ha}^{-1}\right)$ on all $D$. tenuifolia growth stages. In addition, treatment $1\left(0.0675 \mathrm{~kg}\right.$ ae $\left.\cdot \mathrm{ha}^{-1}\right)$ showed no effect on perennial wall-rocket in early and middle stages (Table 4). Gigón et al. (2009) recorded a $91.7 \%$ biomass reduction compared to the untreated control, applying $1.32 \mathrm{~kg}$ ai in Adolfo Alsina (Buenos Aires Province). The dose of $0.135 \mathrm{~kg}$ ae $\cdot \mathrm{ha}^{-1} \mathrm{did}$ not control the weed in either stage, but the remaining plants were stunted (Table 3). Adjusted regression for each plant stage is shown in Figure 2. The effective dose for $90 \%$ control $\left(\mathrm{I}_{90}\right)$ was sevenfold higher in the advanced stage compared to the early stage (Table 5 , Fig. 2 ).

\section{Cynara cardunculus}

Glyphosate at $0.135 \mathrm{~kg}$ ae $\cdot \mathrm{ha}^{-1}$ reduced the biomass at the early and middle vegetative stages of artichoke thistle, providing $100 \%$ control. However, $0.27 \mathrm{~kg}$ ae . - $\mathrm{ha}^{-1}$ was required in order to obtain total control at the advanced stages (Fig. 3). Kelly and Pepper (1996) observed that $1 \mathrm{l} \cdot \mathrm{ha}^{-1}$ of glyphosate was necessary previous to flowering, whereas that rate was not sufficient to control it in the advanced stages. Similarly, the older the plants in Carduus nutans (tribe Cardueae), the less control with glyphosate, obtaining 94.7, 46.8, and $33.6 \%$ control of seedlings, vegetative and mature stages, respectively (Eerensand Mellsop 2008). Eerensand Mellsop (2008) determined $82.8 \%$ control through visual estimation when $0.36 \mathrm{~kg}$ ai $\cdot \mathrm{ha}^{-1}$ with $200 \mathrm{l} \cdot \mathrm{ha}^{-1}$ of spray volume was applied. Monk et al. (1991) observed $90 \%$ control of C. nutans at $1.06 \mathrm{~kg}$ ai $\cdot \mathrm{ha}^{-1}$ when $187 \mathrm{l}$ of spray volume was applied at the rosette stages (about $15 \mathrm{~cm}$ in diameter).

\section{Avena barbata}

Glyphosate at $0.27 \mathrm{~kg}$ ae $\cdot \mathrm{ha}^{-1}$ was sufficient to achieve optimal control of slender wild oat in the early and middle vegetative stages. Conversely, $0.54 \mathrm{~kg}$ ae $\cdot \mathrm{ha}^{-1}$ of glyphosate was necessary to obtain the best results at the advanced stage (Table 4). Similarly, Adkins et al. (1998) obtained a seedling biomass reduction (30 days of age) of A. fatua under field capacity conditions, at $1.8 \mathrm{~kg}$ ai $\cdot \mathrm{ha}^{-1}$ just 10 days after treatment applications. A control of $98-99 \%$ was obtained at two locations in Canada when $0.445 \mathrm{~kg}$ ai $\cdot \mathrm{ha}^{-1}$ was applied to the 1 to 4 leaf stages of $A$. fatua (Blackshaw and Harker 2002). When glyphosate was applied at $0.44 \mathrm{~kg}$ ai $\cdot \mathrm{ha}^{-1}$ to A. fatua, 10 days after flowering, seed production was reduced in the main shoots even though the plants did not die (Shuma et al. 1995). Interestingly, plant height showed the same behavior as dry mass at the used application rates (Table 3 ). The advanced stage required 4.7 fold to achieve $90 \%$ control compared with early stage (Table 5, Fig. 4).

\section{Lolium perenne}

In this study, the optimal glyphosate rate for 100\% control for perennial ryegrass at the early vegetative 


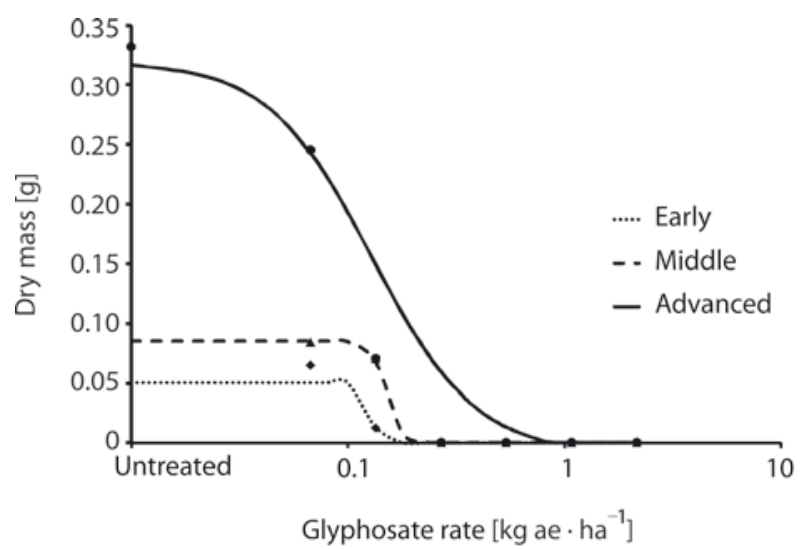

$$
\begin{aligned}
& y_{\text {early }}=-1 \exp -9+(0.05+1 \exp -9) /\left[1+(x / 0.23)^{26.3}\right] ; \quad R^{2}=0.64 \\
& y_{\text {middle }}=-1 \exp -5+(0.08+1 \exp -5) /\left[1+(x / 0.28)^{12.84}\right] ; \quad R^{2}=0.93 \\
& y_{\text {artuancrad }}=-0.01+(0.32+0.01) /\left[1+(x / 0.24)^{1.81}\right] ; \quad R^{2}=0.86
\end{aligned}
$$

Fig. 2. Dose-response curve of glyphosate to three vegetative stages of Diplotaxis tenuifolia measured as a reduction of biomass

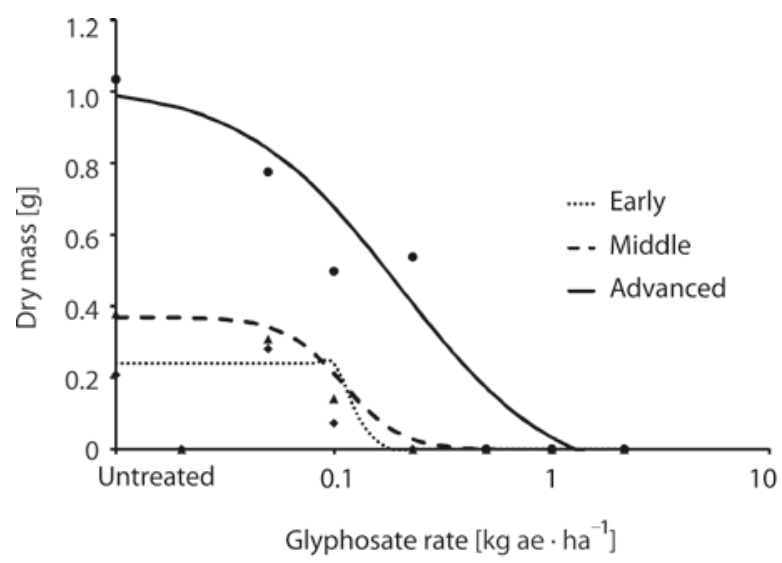

$$
\begin{aligned}
& y_{\text {early }}=-1.4 \exp -8+(0.24+1.4 \exp -8) /\left[1+(x / 0.13)^{22.73}\right] ; \quad R^{2}=0.77 \\
& y_{\text {middle }}=-0.004+(0.37+0.004) /\left[1+(x / 0.11)^{3.21}\right] ; \quad R^{2}=0.81 \\
& y_{\text {artuanrad }}=-0.11+(1.02+0.11) /\left[1+(x / 0.2)^{1.2}\right] ; \quad R^{2}=0.86
\end{aligned}
$$

Fig. 4. Dose-response curve of glyphosate to three vegetative stages of Avena barbata measured as a reduction of biomass

stage was $0.135 \mathrm{~kg} \mathrm{ae} \cdot \mathrm{ha}^{-1}$, whereas in the middle and advanced stages it was $0.27 \mathrm{~kg} \mathrm{ae} \cdot \mathrm{ha}^{-1}$ (Table 4). Similarly, Vigna et al. (2008), who studied L. multiflorum, demonstrated that this weed can be controlled with a mean rate of $0.392 \mathrm{~kg}$ ai $\cdot \mathrm{ha}^{-1}$, whereas at the $10 \mathrm{~cm}$ shoot length stage (flowering), 0.6 to $1.2 \mathrm{~kg}$ ai $\cdot \mathrm{ha}^{-1}$ were effective. In the present study, a spray dose of $1.08 \mathrm{~kg} \mathrm{ae} \cdot \mathrm{ha}^{-1}$ was required to kill $90 \%$ of the plants. In middle and advanced stages the rate of $0.135 \mathrm{~kg}$ ai $\cdot \mathrm{ha}^{-1}$ did not kill the plant but reduced plant height (Table 3). The effective dose for $90 \%$ control was only twofold higher in advanced stages than early growth stages (Table 5, Fig. 5).

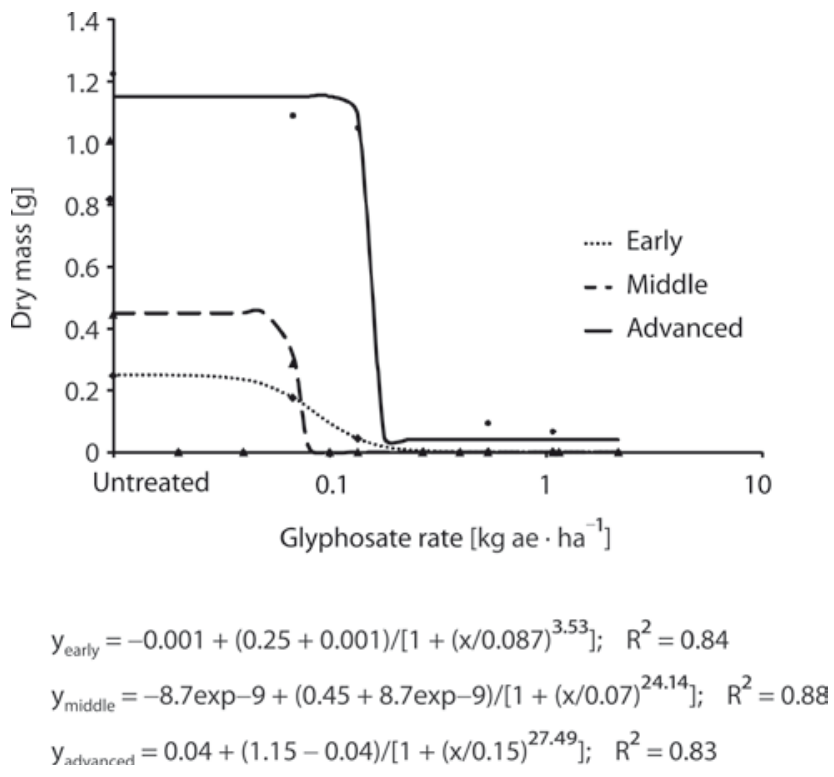

Fig. 3. Dose-response curve of glyphosate to three vegetative stages of Cynara cardunculus measured as a reduction of biomass

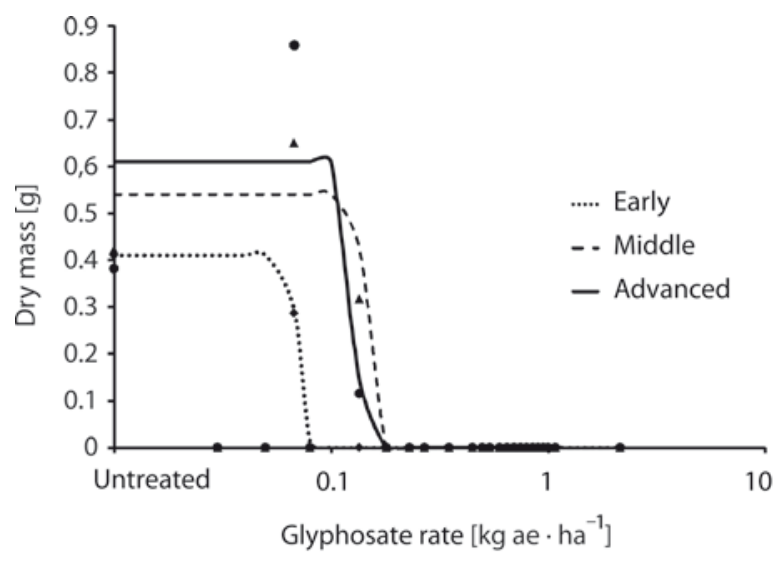

$$
\begin{aligned}
& y_{\text {early }}=-4.24 \exp -9+(0.41+4.24 \exp -9) /\left[1+(x / 0.07)^{25.45}\right] ; \quad R^{2}=0.62 \\
& y_{\text {middle }}=-2.57 \exp -12+(0.54+2.57 \exp -12) /\left[1+(x / 0.14)^{36.14}\right] ; \quad R^{2}=0.86 \\
& y_{\text {advanced }}=-2.66 \exp -9+(0.61+2.66 \exp -9) /\left[1+(x / 0.13)^{29.96}\right] ; \quad R^{2}=0.80
\end{aligned}
$$

Fig. 5. Dose-response curve of glyphosate to three vegetative stages of Lolium multiflorum measured as a reduction of biomass

All of the weed species studied in SW Buenos Aires were effectively controlled with glyphosate at lower rates than those recommended; moreover, the results observed in this study agree with other research which indicates that the higher the weed relative cover, the less the susceptibility to herbicides (Puricelli and Faccini 2009). It is known that plants at the early growth stages are more susceptible to herbicides, due to greater absorption of the herbicide by young and rapidly growing plants than mature ones. Similarly, certain studies reported greater control with glyphosate in common fathen (Chenopodium album) when plants were relatively smaller 
than large sizes (Schuster et al. 2007). Besides the increasing leaf area, there are also important changes in the cuticle features. The variations in cuticle and wax deposition may affect glyphosate efficacy (Boutin et al. 2012). Hence, the largest doses were needed to control the oldest plants.

According to the average $\mathrm{I}_{50}$ determined at different phenological stages, the least susceptible weed species to glyphosate was D. tenuifolia, followed by A. barbata, L. multiflorum, and finally by C. cardunculus.

In conclusion, it is highly important to take into account that early weed herbicide applications reduce the optimal doses substantially. In this study, advanced stages required higher rates to control the weeds. In this case, lower rates $\left(0.27 \mathrm{~kg}\right.$ ae $\left.\cdot \mathrm{ha}^{-1}\right)$ can only be used on the early vegetative stages to achieve the highest effects on the typical weeds found in SW Buenos Aires province. Recommended doses for middle vegetative stages could be approximately $0.54 \mathrm{~kg}$ ae $\cdot \mathrm{ha}^{-1}$ in broadleaf species and $0.27 \mathrm{~kg}$ ae $\cdot \mathrm{ha}^{-1}$ in grasses. Advanced stages would require rates of $1.08 \mathrm{~kg}$ ae $\cdot \mathrm{ha}^{-1}$ to obtain an acceptable control. Interestingly, early and middle growth stages of all the species were successfully controlled with lower rates than the label dose. Advanced growth stage plants needed the recommended dose to achieve an effective control.

\section{Interaction with 2,4-D}

Glyphosate in combination with 2,4-D showed $100 \%$ control after 30 days of treatment on all the vegetative stages of the broadleaf species, similar to glyphosate applied alone at the recommended dose. Likewise, Gigón et al. (2009) obtained 96.3\% control using analogous rates of glyphosate and $250 \mathrm{ml} \cdot \mathrm{ha}^{-1}$ of 2,4-D. In some situations, glyphosate in combination with 2,4-D resulted in an increase in the metabolical activity, improving glyphosate transport and eventually leading to effective control (Flint and Barrett 1989). It is generally known that neutral or antagonistic responses can also occur with herbicide mixtures (Fish et al. 2015). In our study, the addition of 2,4-D to glyphosate did not increase the control efficacy on the tested species.

\section{Conclusion}

Glyphosate treatments are the most frequently used control techniques in SW Buenos Aires province. In order to avoid weeds escaping and enabling sustainable management, it is necessary to spray with the appropriate dose for the precise plant size and phenological stage. This study showed that plants were highly susceptible to glyphosate treatments under the sprayer conditions used in this research. While early and middle growth were easily controlled with half of the label application rate, advanced stages required the recommended dose. Moreover, the addition of 2,4-D to glyphosate did not produce any increase in the control of the broadleaf weeds. When applications are carried out correctly, glyphosate used alone at reduced rates could be a useful tool for weed control in the south west of Buenos Aires province.

\section{Acknowledgements}

The authors wish to thank Monsanto Argentina for glyphosate supply for this research.

\section{References}

Abramoff M.D., Magalhaes P.J., Ram S.J. 2004. Image processing with Image. Journal of Biophotonics International 11: $36-42$.

Adkins S.W., Tanpipat S., Swarbrick J.T., Boersma M. 1998. Influence of environmental factors on glyphosate efficacy when applied to Avena fatua or Urochloa panicoides. Weed Research 38:129-138. DOI: https://doi.org/10.1046/j.13653180.1998.00083.x

Alvarez R., Steinbach H.S. 2009. A review of the effects of tillage systems on some soil physical properties, water content, nitrate availability and crops yield in the Argentine Pampas. Soil and Tillage Research 104: 1-15. DOI: https://doi. org/10.1016/j.still.2009.02.005

Baylis A.D. 2000. Why glyphosate is a global herbicide: strengths, weaknesses and prospects. Pest Management Science 56 (4): 299-308. DOI: https://doi.org/10.1002/(SICI)1526-4998(200004)56:4<299::AID-PS144>3.0.CO;2-K

Blackshaw R.E., Harker K. 2002. Selective weed control with glyphosate in glyphosate-resistant spring wheat (Triticum aestivum). Weed Technology 16 (4): 885-892. DOI: https://doi. og/10.1614/0890-037X(2002)016[0885:SWCWGI]2.0.CO;2

Boutin C., Aya K.L., Carpenter D., Thomas P.J., Rowland O. 2012. Phytotoxicity testing for herbicide regulation: shortcomings in relation to biodiversity and ecosystem services in agrarian systems. Science of the Total Environment 415: 79-92. DOI: https://doi.org/10.1016/j.scitotenv.2011.04.046.

Di Rienzo J.A., Casanoves F., Balzarini M.G., González L., Tablada M., Robledo C.W. 2015. INFOSTAT, versión 2015. Grupo Infostat, FCA. Universidad Nacional de Córdoba, Argentina.

Eerens H., Mellsop J. 2008. Matching herbicide application rates with the environmental conditions and growth stages of nodding thiste (Carduus nutans) and hairy buttercup ( $R a$ nunculus sardous) in pastures. Weed Biology and Management 8 (3): 209-214. DOI: https://doi.org/101111/j.14456664.2008.00297.x

Esehaghbeygi A., Tadayyon A., Besharati S. 2011. Effect of droplet size on weed control in wheat. Journal of Plant Protection Research 51 (1): 18-22. DOI: https://doi.org/ 10.2478/ v10045-011-0004-1

Fish J.C., Webster E.P., Blouin D.C., Bond J.A. 2015. Imazethapyr co-application interactions in imidazolinone-resistant rice. Weed Technology 29 (4): 689-696. DOI: https://doi.org/ 10.1614/WT-D-15-00030.1

Flint J.L., Barrett M. 1989. Effect of glyphosate combinations with 2,4-D or dicamba on field bindweed (Convolvulus arvensis). Weed Science 37 (1): 12-18.

Ganie Z.A., Jugulam M., Jhala A.J. 2017. Temperature influences efficacy, absorption, and translocation of 2,4-D or glyphosate in glyphosate-resistant and glyphosate-suscep- 
tible common ragweed (Ambrosia artemisiifolia) and giant ragweed (Ambrosia trifida). Weed Science 65 (5): 588-602. DOI: https://doi.org/10.1017/wsc.2017.32

Gigón R., Lageyre E., Vigna M., López R., Coria M., Labarthe F. 2009. Relación costo/beneficio en el control químico de Diplotaxis tenuifolia L. y Centaurea solstitialis L. en una pastura degradada de alfalfa (Medicago sativa L.) del Sudoeste Bonaerense [Cost/benefit relationship in the chemical control of Diplotaxis tenuifolia L. and Centaurea solstitialis L. in a degraded pasture of alfalfa (Medicago sativa L.) of the Southwest of Buenos Aires.] Anales de la XL Reunión de la Asociación Argentina de Economía Agraria, CD - ISSN 1666-0285, Libro de Resúmenes y www.aaea.org.ar, Bahía Blanca. (in Spanish)

Istilart C., Yanniccari M. 2013. Análisis de la evolución de las malezas en cereales de invierno durante 27 años en la zona sur de la pampa húmeda argentina [Analysis of the evolution of weeds in winter crop for 27 years in the southern part of the Argentine humid pampa]. Actualización técnica en cultivos de cosecha fina 2012/13, 113. (in Spanish)

Juan V.F., Irigoyen J.H., Orioli G.A. 1995. Effect of post-emergence graminicides on the control of Avena fatua. Planta Daninha 13: 10-13. DOI: https://doi.org/10.1590/S010083581995000100002

Kelly M., Pepper A. 1996. Controlling Cynara cardunculus (Artichoke Thistle, Cardoon, etc.). Proceedings of California Exotic Pest Plant Council. 4-6 October, Handlery Hotel, San Diego, California, USA.

Knoche M. 1994. Effect of droplet size and carrier volumen on performance of foliage-applied herbicides. Crop Protection 13 (3): 163-178.

Lamberto S.A., Valle A.F., Aramayo E.M., Andrada A.C. 1997. Manual Ilustrado de las Plantas Silvestres de la Región de Bahía Blanca [Illustrated Manual of Wild Plants of the Bahía Blanca Region]. Departamento de Agronomia, Universidad Nacional del Sur, Bahia Blanca, Argentina, 548 pp. (in Spanish)

Monk D.W., Halcomb M.A., Ashburn E.L. 1991. Survey and control of musk thistle (Carduus nutans) in Tennessee field nurseries. Weed Technology 5 (1): 218-220. DOI: https:// doi.org/10.1017/S0890037X0003356X

Paoloni J.D. 2010. Ambientes y recursos naturales del partido de Bahía Blanca: clima, geomorfología, suelos, y aguas [Environments and natural resources of the Bahía Blanca county: Climate, geomorphology, soils, and waters]. $1^{\text {a }}$ ed
EdiUNS. Bahía Blanca. Unversidad Nacional del Sur, 242 pp. (in Spanish)

Puricelli E., Faccini D. 2009. Efecto de la dosis de glifosato sobre la biomasa de malezas de barbecho al estado vegetativo $y$ reproductivo [Effect of the dose of glyphosate on the biomass of fallow weeds to the vegetative and reproductive state]. Planta Daninha 27 (2): 303-307. DOI: http://doi. org/10.1590/S0100-83582009000200013 (in Spanish)

Schuster C.L., Shoup D.E., Al-Khatib K. 2007. Response of common lambsquarters (Chenopodium album) to glyphosate as affected by growth stage. Weed Science 55 (2): 147-151. DOI: http://doi.org/10.1614/WS-06-130.1

Scursoni J.A., Gigón R., Martín A.M., Vigna M., Leguizamón E.S., Istilart C., López R. 2014. Changes in weed communities of spring wheat crops of Buenos Aires province, Argentina. Weed Science 62 (1): 51-62. DOI: http://doi. org/10.1614/WS-D-12-00141.1

Seefeldt S.S., Jensen J.E., Fuerst E.P. 1995. Log-logistic analysis of herbicide dose-response relationships. Weed Technology 9 (2): 218-227. DOI: https://doi.org/10.1017/ S0890037X00023253

Shuma J.M., Quick W.A., Raju M.V.S., Hsiao A.I. 1995. Germination of seeds from plants of Avena fatua L. treated with glyphosate. Weed Research 35: 249-255. DOI: http://doi. org/10.1111/j.1365-3180.1995.tb01787.x

Skelton J.J., Ma R., Riechers D.E. 2016. Waterhemp (Amaranthus tuberculatus) control under drought stress with 2,4-dichlorophenoxyacetic acid and glyphosate. Weed Biology and Management 16 (1): 34-41. DOI: http://doi.org/10.1111/ wbm.12092

Vigna M.R., Lopez R.L., Gigón R., Mendoza J. 2008. Estudios de curvas dosis-respuesta de poblaciones de Lolium multiflorum a glifosato en el SO de Buenos Aires, Argentina [Studies of dose-response curves of populations of Lolium multiflorum to glyphosate in the SW of Buenos Aires]. p. 1-11. In: Proceedings of the XXVI Brazilian Weed Congress and Latin-American Weed Congress, Ouro Presto, MG Brasil. (in Spanish)

Yanniccari M. 2014. Estudio fisiológico y genético de biotipos de Lolium perenne L. resistentes a glifosato [Physiological and genetic study of glyphosate-resistant Lolium perenne L. biotypes]. Ph.D. thesis, University of La Plata, Argentina, 239 pp.

Zhu H., Salyani M., Fox R.D. 2011. A portable scanning system for evaluation of spray deposit distribution. Computer and Electronics in Agriculture 76 (1): 38-43. DOI: http://doi. org/10.1016/j.compag.2011.01.003 